\title{
The effectiveness of Nigella sativa, methotrexate and their combination in the treatment of moderate to severe psoriasis
}

\author{
Orta ve ağır psoriazis tedavisinde Nigella sativa, metotreksat ve ikisinin kombinasyonlarının \\ etkinliği
}

Jawad Hassan Ahmed ${ }^{1}$, Sheima Nadim Kadhim², Khalil Ismael Al-Hamdi

\begin{abstract}
Objective: Methotrexate (MTX) is a commonly prescribed drug for patients with psoriasis. Nigella sativa (NS) has been shown beneficial in vitiligo and in eczema. Recently, NS has shown activity in modifying psoriatic lesions. The aim of this study was to evaluate the effect of the combination (NS+MTX) on psoriasis and to compare that with NS or MTX monotherapy.
\end{abstract}

Methods: Sixty patients with moderate to severe plaque, palmoplantar and guttate psoriasis were enrolled for 12 weeks study. The patients were divided into 3 groups; 20 patients in each. Group 1 was treated with NS ointment $(20 \% \mathrm{w} / \mathrm{w}) 2$ times daily $+500 \mathrm{mg}$ NS capsule 3 times daily. Group 2 received MTX tablets $15 \mathrm{mg}$ weekly and group 3 received MTX + NS (topical + oral).

Results: Marked response was achieved in $60 \%, 80 \%$, and $90 \%$ of patients on NS, MTX, and (NS + MTX) respectively. The respective relapse rate was $33.3 \%$, $56.3 \%$, and $27.8 \%$. Serum malondialdehyde (sMDA), a parameter of oxidative stress was decreased from 4.39 \pm 0.81 to $2.31 \pm 0.72 \mu \mathrm{mol} / \mathrm{L}$ with NS treatment while a small increase in SMDA was observed with MTX. NS + MTX treatment reduced SMDA from $4.39 \pm 0.67$ to 3.49 $\pm 0.65 \mu \mathrm{mol} / \mathrm{L}$ after 12 weeks treatment. All treatments did not change liver enzymes or complete blood count. NS was well tolerated and showed ability in ameliorating gastric upset of MTX.

Conclusion: NS augments antipsoriatic effect of MTX. Topical and oral use of NS is effective and safe in moderate to severe psoriasis. J Clin Exp Invest 2014; 5 (4): $521-528$

Key words: Psoriasis, methotrexate, Nigella sativa

\section{ÖZET}

Amaç: Metotreksat (MTX) psöriazisli hastalarda sıklıkla kullanılan bir ilaçtır. Nigella sativa (NS - çörek otu)'nun vitiligo ve egzemada yaralı olduğu gösterilmiştir. Yakın zamanda NS'nin psöriatik lezyonları modifiye etmede etkin olduğu gösterildi. Bu çalışmanın amacı psöriazisde MTX+NS kombinasyonunun etkisini değerlendirmek ve bu etkinin NS ve MTX'in tek başına olan etkinliği ile karşılaştırmaktır.

Yöntemler: Orta-ağır plak, palmoplantar ve guttat psöriazisli 60 hasta 12 haftalık çalışmaya alındı. Hastalar her grupta 20'şer hasta olacak şekilde 3 gruba ayrıldı. Grup 1'e günde 2 kez uygulanan NS merhemi (\%20'lik)'ne ilaveten günde 3 kez 500 mg NS kapsülleri verildi. Grup 2 haftada bir 15 mg MTX tableti aldı ve Grup 3'e MTX+NS (Topikal ve oral) verildi.

Bulgular: NS, MTX ve NS+MTX gruplarında sırasıyla $\% 60, \% 80$ ve $\% 90$ cevap alındı. NS tedavisi ile oksidatif stres belirteci olan serum malondialdehid (sMDA) 4,39 \pm 0,81 $\mu \mathrm{mol} / \mathrm{L}^{\prime}$ den 2,31 \pm 0,72 $\mu \mathrm{mol} / \mathrm{L}^{\prime} y e$ düştü, ancak MTX ile sMDA'da hafif artış gözlendi. 12 haftalık MTX ve NS+MTX tedavilerini takiben SMDA $4.39 \pm 0.67 \mu \mathrm{mol} /$ L'den $3.49 \pm 0.65 \mu \mathrm{mol} /$ L'ye indi. Tedavilerin tümünde karaciğer enzimleri ve tam kan sayımlarında bir değişiklik gözlenmedi. NS iyi tolere edildi ve MTX'in yaptığı mide rahatsızlığını iyileştirici etkisi gözlendi.

Sonuç: NS, MTX'in anti-psöriatik etkisini kuvvetlendirdi. Topikal ve oral NS kullanımı orta ve ağır psöriazisde etkin ve güvenlidir.

Anahtar kelimeler: Psöriazis, metotreksat, Nigella sativa

\footnotetext{
${ }^{1}$ Assistant Professor, PhD pharmacology, Department of Pharmacology, College of Medicine, University of Basrah, Iraq

${ }^{2}$ Assistant lecturer, BSc Pharmacy, Department of Pharmacology, College of pharmacy, University of Basrah, Iraq

${ }_{3}^{3}$ Professor of Dermatology, Department of Dermatology, College of Medicine, University of Basrah, Iraq

Correspondence: Ahmed JH, Department of Pharmacology, College of Medicine, University of Basrah, Iraq Email: jawadahmed_basmed@yahoo.com

Received: 11.09.2014, Accepted: 08.10.2014

Copyright @ JCEI / Journal of Clinical and Experimental Investigations 2014, All rights reserved
} 


\section{INTRODUCTION}

Psoriasis is a common, chronic and recurring inflammatory skin disease [1] with prevalence in general population of $3.15 \%$ [2]. Many drug regimens are available to reduce the severity of symptoms and lessen patient's sufferings [3]. These are either topical or systemically administered drugs such as Methotrexate (MTX), cyclosporine, hydroxyurea, thioguanine and other drugs which are potentially toxic and require close monitoring [3], in addition to their high prices [4]. NS is a medicinal plant, which has been investigated in many diseases. In skin diseases, it has been shown beneficial in vitiligo [5] and in eczema of the hand [6]. In a recent study, our team has found that Nigella sativa (NS) as topical or oral dosage form has antipsoriatic effect in patients with mild to moderate psoriasis [7]. In moderate to severe psoriasis, MTX is an indispensable drug but frequently causes serious side effects. It is therefore thought that combining NS + MTX may have dual effects; an additive antipsoriatic effects, and since NS is known to have antioxidant [8] and hepatoprotective effects [9], it may modify MTX associated toxic side effects.

\section{METHODS}

\section{Patients selection}

Sixty-eight patients with moderate to severe psoriasis attending the Department of Dermatology and Venereology in Al-Sadder Teaching Hospital in Basrah during the period November 2011 to December 2012 were recruited. Eight patients were defaulted at various stages, sixty patients had completed the study. Initial sample size was calculated according to a formula for one-tailed unpaired t-test [10] to detect a difference of $25 \%$ in PASI (Psoriasis Area and Severity Index) score with $80 \%$ power of test. Sample size was recalculated after exclusion of patients. Male and female were involved, age ranged between 5-70 years. Those patients on topical or systemic treatment were asked to stop their treatment two weeks before the study and kept on Vaseline ointment as emollient agent. Detailed history such as duration of the disease, present and past treatment history, family history, occupation, residency and smoking were obtained. Patients were seen every two weeks for 12 weeks.

\section{Preparation of NS ointment}

The seeds of NS were purchased from a local market for medicinal plants in Basrah city center, authenticated by an expert herbalist and a voucher specimen of the seeds was kept in the Department of Pharmacology for future reference. The seeds were further tested for viability by cultivating 100 seeds, count the implanted number of the plants and follow up its growth. The essential oil of NS was extracted by Soxhlet method [11] with a yield of $20 \%$. The ointment was prepared by mixing $20 \mathrm{gm}$ of the essential oil of NS with $80 \mathrm{gm}$ of white Vaseline (petrolatum) melted in a water bath at $40^{\circ} \mathrm{C}$. The mixture was stirred manually until a homogenized ointment was obtained.

\section{Preparation of capsule dosage form}

The seeds was grinded to a fine powder using electric grinder. The powder was then filled into gelatin capsules (size 0). Each capsule contained $500 \mathrm{mg}$.

\section{Study design}

This study was an open-label, therapeutic, outpatient-based study. The patients were informed about the nature of the study and written informed consents were obtained from all participants. The patients were also informed that a direct benefit may not be guaranteed. The study protocol obtained an ethical approval from a local institutional ethical committee. A sequential numbered list was generated and used for randomization of patients for the 3 groups. The study was matched for gender and type of psoriasis. Group 1 (20 patients) were treated with NS (topical + oral). For topical application, a thin layer of $20 \% \mathrm{w} / \mathrm{w}$ ointment of NS was applied on the affected area twice daily, in the morning and evening. For oral dosing a $500 \mathrm{mg}$ capsule of NS three times daily was used; group 2 (20 patients) were treated with MTX tablets $15 \mathrm{mg}$ weekly. One patient aged less than 15 years was selected by randomization list for MTX treatment, a decision was made to substitute this patient with a patient from group 1 to avoid MTX treatment for this age; Group 3 (20 patients) were treated with the combination MTX tablets $15 \mathrm{mg}$ weekly + NS (topical + oral) at the previously described doses. Folate was given to all patients on MTX monotherapy or the combination. The treatment continued for 12 weeks. During this period, the patients were seen every 2 weeks for evaluation of response and monitoring of side effects. Follow up were continued for 4 weeks after cessation of treatment for evaluation of relapse.

\section{Measurement and assessment of response}

\section{Clinical assessment}

PASI score was employed for evaluation of the extent of the disease and for monitoring therapeutic 
response [12]. PASI score was monitored before, during and after treatment and presented as \% reduction from baseline values.

Patients were considered responders if a reduction in PASI of $50 \%$ or more were observed. Response to treatment was divided arbitrarily into the following categories: complete cure when psoriatic lesions completely cleared (100\%), excellent, good, partial and no response when the \% reductions in PASI score were $75-99 \%, 50-74 \%, 25-49 \%$, and $<25 \%$ respectively. Relapse of the disease was considered only for patients who experienced more than $50 \%$ improvement to treatment, then fell below this level 4 weeks after cessation of treatment [13].

\section{Laboratory measurements}

\section{Measurement of Malondialdehyde (MDA) in the serum}

MDA formed from the breakdown of polyunsaturated fatty acid, serves as a convenient index for the extent of peroxidation reaction. It was measured according to the method of Bueg and Aust, 1978 [14].

\section{Measurement of liver enzymes and complete blood count}

For patients safety, liver enzymes (ALT and AST) and complete blood count were measured every 4 weeks.

\section{Photographic viewing}

Photographs were taken every 2 weeks using a high resolution digital camera (16 mega pixel max).

\section{Statistical analysis}

SPSS version 17 was used for data analysis. Because of the non-linear nature of data, KruskalWallis, a non-parametric test was used for testing differences between means of the 3 groups. MannWhitney $U$ test was used for testing differences between means of two groups. $P$ value less than 0.05 was considered significant.

\section{RESULTS}

Sixty patients had completed the study with a mean age of $35.5 \pm 12.4$ years; 23 patients were females with a mean age of $35 \pm 13.3$ years; 37 were males, mean age (43.9 \pm 17.9 years) (Table 1). Twenty patients were diagnosed with palmoplantar psoriasis of the hands and feet, 6 patients were having guttate psoriasis and the rest were diagnosed as plague psoriasis.

Table 1. Patients characteristics

\begin{tabular}{cccc}
\hline \multirow{2}{*}{ Age, years } & \multicolumn{2}{c}{ Number of patients } & \multirow{2}{*}{ Total } \\
\cline { 2 - 3 } & Males & Females & \\
\hline $5-14$ & 1 & 1 & 2 \\
$15-24$ & 7 & 5 & 12 \\
$25-34$ & 11 & 7 & 18 \\
$35-44$ & 3 & 4 & 7 \\
$45-54$ & 5 & 5 & 10 \\
$55-64$ & 6 & 0 & 6 \\
$65-74$ & 4 & 1 & 5 \\
60 & 37 & 23 & \\
\hline Mean \pm SD & $35.5 \pm 12.4$ & $43.9 \pm 17.9$ & $35 \pm 13.3$ \\
\hline
\end{tabular}

SD: Standard deviation

\section{Clinical assessment of response to treatment}

The mean baseline value of PASI score declined from $22.9 \pm 4.3$ to $19.6 \pm 4,17.7 \pm 4.2,15.9 \pm 4.6$, $14.3 \pm 4.9,12.5 \pm 4.7$ and $9.2 \pm 4.5$ at the end of 2,4 , $6,8,10$ and 12 weeks of treatment with NS (topical + oral) respectively, The differences from baseline were highly significant, $\mathrm{P}<0.0001$ (Table 2). The same pattern of change was observed with MTX treatment and even better response was observed with the combination MTX + NS (topical + oral) (Table 2). For the sake of clarity, the PASI scores were presented as \% reduction from baseline.

Table 2. The effect of treatments on PASI score (Mean \pm SD) at 2, 4, 6, 8, 10 and 12 weeks

\begin{tabular}{cccc}
\hline \multirow{2}{*}{ Weeks } & $\begin{array}{c}\text { Group 1 } \\
\text { NS }(n=20)\end{array}$ & $\begin{array}{c}\text { Group 2 } \\
\text { MTX }(n=20)\end{array}$ & $\begin{array}{c}\text { Group 3 } \\
\text { MTX + NS }(n=20)\end{array}$ \\
\hline Baseline & $22.9 \pm 4.3$ & $23.4 \pm 3.9$ & $28.2 \pm 4.3$ \\
2 & $19.6 \pm 4^{*}$ & $19.5 \pm 3.4^{*}$ & $22.7 \pm 4^{*}$ \\
4 & $17.7 \pm 4.2^{*}$ & $16.9 \pm 2.7^{*}$ & $19.7 \pm 3.5^{*}$ \\
6 & $15.9 \pm 4.6^{*}$ & $14 \pm 2.9^{*}$ & $15.1 \pm 3.7^{*}$ \\
8 & $14.3 \pm 4.9^{*}$ & $11.3 \pm 2.3^{*}$ & $11.7 \pm 3.5^{*}$ \\
10 & $12.5 \pm 4.7^{*}$ & $9.4 \pm 2.7^{*}$ & $9 \pm 4^{*}$ \\
12 & $9.2 \pm 4.5^{*}$ & $7.1 \pm 3.3^{*}$ & $6.8 \pm 3.9^{*}$ \\
\hline
\end{tabular}

PASI score: Psoriasis Area and Severity Index score MTX: Methotrexate; NS: Nigella sativa (topical + oral) ${ }^{*} \mathrm{P}$-value $<0.0001$

The mean \% reduction of PASI score from baseline for patients treated with NS (topical + oral) was $23.1 \pm 8.4 \%$ which significantly increased to 
$37.8 \pm 14.8 \%$ and $60.75 \pm 15.4 \%$ at 8 and 12 weeks respectively, $\mathrm{P}<0.0001$ (Table 3 ).

In patients treated with MTX alone, the mean \% reduction of PASI score from baseline was significantly increased from $27.5 \pm 6.2 \%$ to $51.1 \pm 10.4 \%$, and $69.3 \pm 16.3 \%$ at 8 and 12 weeks respectively, $\mathrm{P}<0.0001$ (Table 3). Overall, it was slightly higher than the effect produced by NS (topical + oral). The combination MTX + NS (topical + oral) achieved mean \% reduction of PASI score from baseline greater than other treatment modalities. It was 57.6 $\pm 11.2 \%$ and $74.6 \pm 14.4 \%$ at 8 and 12 weeks respectively compared with four weeks value of 30.3 $\pm 5.4 \%$ (Table 3 ).

Table 3. \% reduction of PASI score from baseline at the end of 4,8 and 12 week following treatments (Mean \pm SD)

\begin{tabular}{cccc}
\hline Weeks & $\begin{array}{c}\text { Group 1 } \\
\text { NS } \\
(\mathrm{n}=20)\end{array}$ & $\begin{array}{c}\text { Group 2 } \\
\text { MTX tablets } \\
(\mathrm{n}=20)\end{array}$ & $\begin{array}{c}\text { Group 3 } \\
\text { MTX+NS } \\
(\mathrm{n}=20)\end{array}$ \\
\hline 4 & $23.1 \pm 8.4 \%$ & $27.5 \pm 6.2 \%$ & $30.3 \pm 5.4 \%$ \\
8 & $37.8 \pm 14.8 \%{ }^{*}$ & $51.1 \pm 10.4 \%{ }^{*}$ & $57.6 \pm 11.2 \%{ }^{*}$ \\
12 & $60.8 \pm 15.4 \%{ }^{*}$ & $69.3 \pm 16.3 \%{ }^{*}$ & $74.6 \pm 14.4 \%{ }^{*}$ \\
\hline
\end{tabular}

PASI score: Psoriasis Area and Severity Index score MTX: Methotrexate; NS: Nigella sativa (topical + oral) ${ }^{*}$ P-value $<0.001$

\section{Response to treatments}

Marked responses defined as complete cure of psoriatic lesions, excellent and good, were noted in $90 \%$ of patients on the combination of MTX + NS (topical + oral). While the same responses were seen in $80 \%$ and $60 \%$ of patients treated with MTX only (group 2) and NS (topical + oral) respectively (Table 4). Partial response was noted in $25 \%, 10 \%$ and $5 \%$ of patients on NS (topical + oral), MTX and the combination of MTX + NS (topical + oral) respectively (Table 4).

\section{Onset of response and relapse rate}

The onset of response was marked after 4 weeks of treatment with the combination of MTX + NS (topical + oral). The onset of action was faster in patients treated with the combination than with other two treatments, for which improvement became clinically evident after 2 weeks of treatment. Four weeks after cessation of treatment, the disease has relapsed in $27.77 \%, 33.33 \%$ and $56.25 \%$ of patients on the combination MTX+ NS (topical + oral), NS (topical + oral), and MTX treatments respectively (Table 4).
Table 4. Response to treatments at the end of 12 weeks

\begin{tabular}{lccc}
\hline $\begin{array}{l}\text { Response / } \\
\text { Relapse }\end{array}$ & $\begin{array}{c}\text { Group 1 } \\
\text { NS n (\%) }\end{array}$ & $\begin{array}{c}\text { Group 2 } \\
\text { MTX n (\%) }\end{array}$ & $\begin{array}{c}\text { Group 3 } \\
\text { MTX+NS n (\%) }\end{array}$ \\
\hline Complete cure & $1(5 \%)$ & $3(15 \%)$ & $8(40 \%)$ \\
Excellent cure & $2(10 \%)$ & $4(20 \%)$ & $3(15 \%)$ \\
Good response & $9(45 \%)$ & $9(45 \%)$ & $7(35 \%)$ \\
Partial response & $5(25 \%)$ & $2(10 \%)$ & $1(5 \%)$ \\
No response & $3(15 \%)$ & $2(10)$ & $1(5 \%)$ \\
Relapse rate & $3(33.3 \%)$ & $9(56.3 \%)$ & $5(27.3 \%)$ \\
\hline
\end{tabular}

MTX: Methotrexate; NS: Nigella sativa (topical + oral)

\section{Effect oftreatments on serum malondialdehyde (sMDA)}

The mean baseline serum malondialdehyde (sMDA) was $4.39 \pm 0.81 \mu \mathrm{mol} / \mathrm{L}$, which was decreased to $2.31 \pm 0.72 \mu \mathrm{mol} / \mathrm{L}$ after 12 weeks treatment with NS (ointment + oral). This reduction was statistically highly significant $(P<0.001)$ (Table 5$)$.

Table 5. Serum malondialdehyde levels before and after 12 weeks of treatment

\begin{tabular}{lccc}
\hline & \multicolumn{2}{c}{ Serum MDA } & \multirow{2}{*}{$p$} \\
\cline { 2 - 3 } & Baseline & 12 weeks & \\
\hline MTX, $\mathrm{n}=13$ & $4.37 \pm 0.81$ & $4.63 \pm 0.81^{*}$ & $<0.001$ \\
NS, $\mathrm{n}=20$ & $4.39 \pm 0.81$ & $2.31 \pm 0.22^{*}$ & $<0.001$ \\
MTX+NS, $\mathrm{n}=20$ & $4.39 \pm 0.67$ & $3.49 \pm 0.65^{*}$ & $<0.001$ \\
\hline
\end{tabular}

MDA: Malondialdehyde; MTX: methotrexate; NS: Nigella sativa (topical + oral)

* Significantly decreased $(P$-value $<0.001)$ from the corresponding baseline value

* Significantly increased $(P$-value $<0.001)$ from the corresponding baseline value

S. MDA was measured in 13 out of 20 patients treated with MTX tablets. The mean baseline SMDA in this group was $4.37 \pm 0.81 \mu \mathrm{mol} / \mathrm{L}$, increased to $4.63 \pm 0.81 \mu \mathrm{mole} / \mathrm{L}$ at 12 weeks of treatment, $\mathrm{P}<0.001$ (Table 6).

In patients on the combination of MTX + NS (ointment + oral), the mean baseline sMDA was $4.39 \pm 0.67 \mu \mathrm{mole} / \mathrm{L}$, which was significantly decreased to $3.49 \pm 0.65 \mu \mathrm{mol} / \mathrm{L}$ at 12 weeks of treatment, $(P<0.001)$ (Table 6).

\section{The effects of NS, MTX or their combination on biochemical parameters}

Liver enzymes (ALT, AST) and complete blood count were measured and found not affected by treatments. 


\section{Photographic viewing of response}

Photographs of psoriatic lesions were taken for all patients before, and at the end of 12 weeks treatment. A representative subject with palmoplantar psoriasis for each set of treatment was presented in figure 1. Partial improvement was noticed in patients on MTX monotherapy; (figure $1 \mathrm{a}, \mathrm{b}$ ); Marked improvement was noticed in patients on NS (topical + oral) (figure $1 \mathrm{c}, \mathrm{d}$ ); and excellent improvement was noticed in patients treated with the combination of MTX + NS (topical + oral) (figure $1 \mathrm{e}, \mathrm{f}$ ).
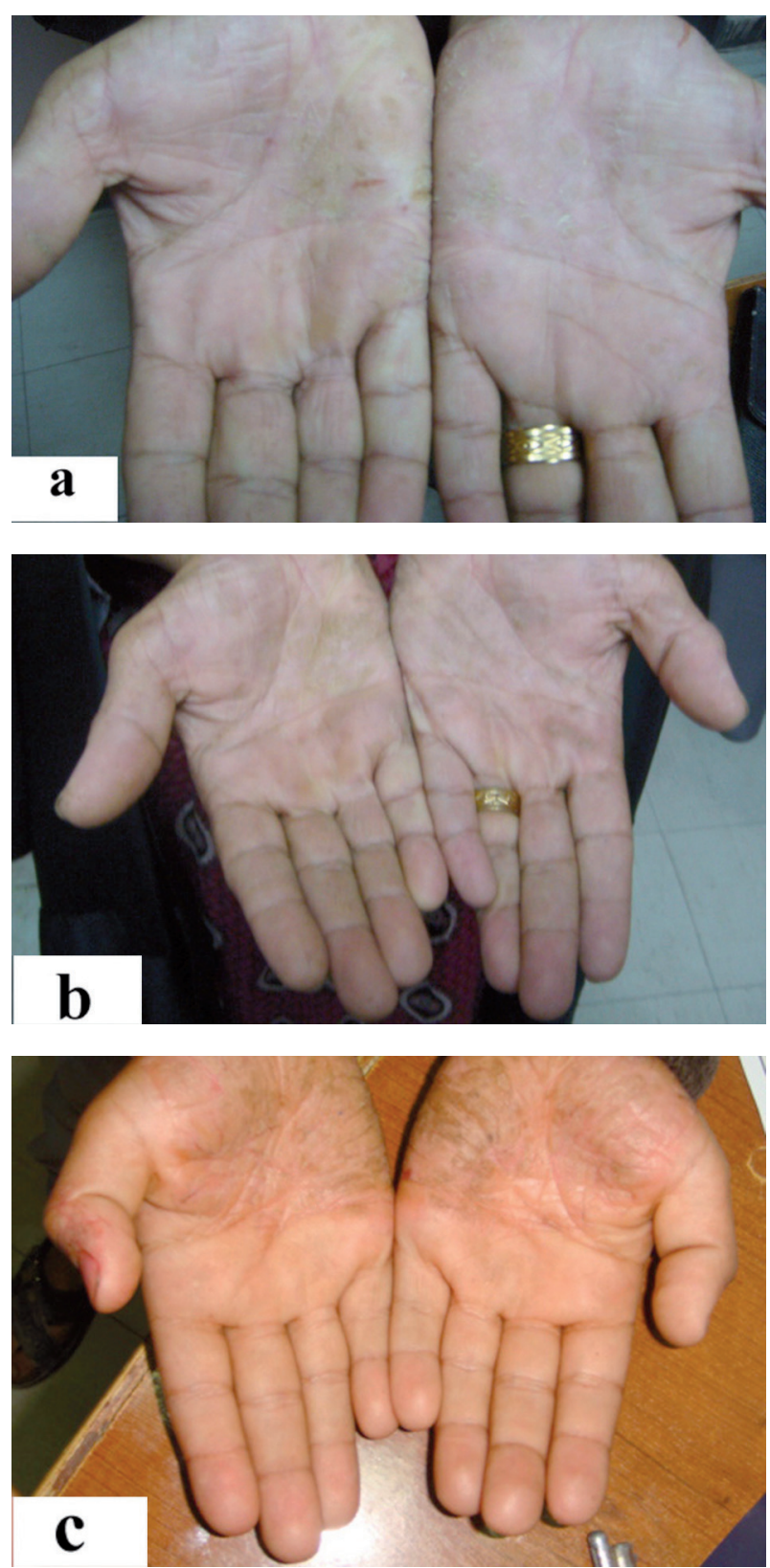
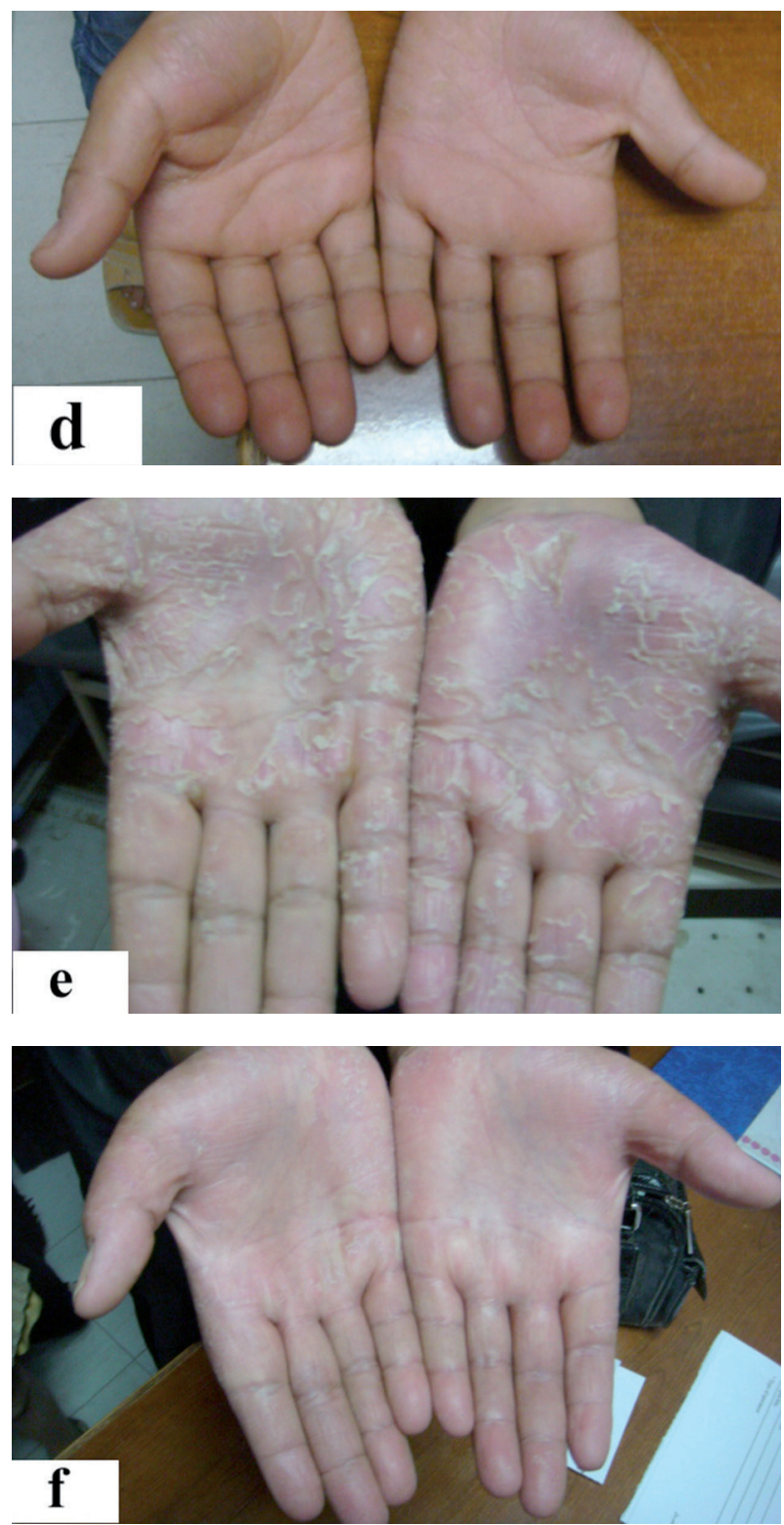

Figure 1. Representative photographs of 3 patients with palmoplantar psoriasis treated with the following drugs: a (before), b (after treatment with MTX); c (before), d (after treatment with NS); e (before), $\mathbf{f}$ (after treatment with the combination MTX + NS (topical + oral). Treatment was continued for 12 weeks.

\section{Patient satisfaction}

High satisfaction was reported in $80 \%$ of patients on NS (topical + oral), $15 \%$ in patients treated with MTX, and in $40 \%$ of patients on MTX + NS (topical + oral) (Table 6). 
Table 6. Patients satisfaction

\begin{tabular}{lccc}
\hline \multirow{2}{*}{ Groups } & \multicolumn{3}{c}{ Satisfaction, n (\%) } \\
\cline { 2 - 4 } & $\begin{array}{c}\text { Not } \\
\text { satisfied }\end{array}$ & $\begin{array}{c}\text { Partially } \\
\text { satisfied }\end{array}$ & $\begin{array}{c}\text { Highly } \\
\text { satisfied }\end{array}$ \\
\hline NS (topical+ oral) & $2(10)$ & $2(10)$ & $16(80)$ \\
MTX & $12(60)$ & $5(25)$ & $3(15)$ \\
MTX + NS & $3(15)$ & $9(45)$ & $8(40)$ \\
(topical + oral) & & & \\
\hline
\end{tabular}

MTX: methotrexate; NS: Nigella sativa

\section{Side effects}

NS was well tolerated without reported side effects. Ninety five percent of patients on oral MTX reported sever gastric upset which did not change in severity despite supplementation of folic acid. Strikingly, this symptom completely disappeared in all patients on the combination of orally administered NS with MTX.

\section{DISCUSSION}

Psoriasis is a common, chronic, relapsing, distressing skin disease with no unique curative systemic or topical treatment. Although the disease is not fatal, it may threaten patient's life as many patients may attempt suicide [3]. A variety of compounds or herbs were investigated in psoriasis. Recently, in a study carried out by our team, the effectiveness of NS (Black Cumin) was evaluated in mild to moderate psoriasis with promising results [7]. The present study is a continuation to that study with an opportunity to evaluate the effect of NS alone or in combination with a weekly oral doses of MTX in patients with moderate to severe plague and palmoplantar psoriasis.

Palmoplantar psoriasis is described as the most difficult type of psoriasis to treat. It has limited response to standard agents as MTX, cyclosporine and acitretin [15]. The observed effect of NS in this type of psoriasis may indicate that the ointment has the ability to penetrate the thick epidermis of the palms and soles and exerts its effect in these sites. The combination MTX + NS (topical + oral) is more effective that NS or MTX monotherapy.

NS has a wide range of pharmacological effects which may contribute to its antipsoriatic effects; these are: immunomodulation [16], antiangiogenesis [17,18], antiproliferative [19], antioxidant $[8,20]$, anti-inflammatory [21], antibacterial [22] and antihistaminic effects [23]. In addition, it contains zinc which is part of its activity in treatment of zinc deficient patients with psoriasis [24]. It was reported that there is an imbalance in the oxidant-antioxidant system in psoriasis [25], and thus a drug or a substance with antioxidant activity could have a role in the treatment of psoriasis [26]. It is more likely that the antipsoriatic effect of NS may in part be explained by its antioxidant activity [8], MTX on the contrary, is known to cause oxidative stress $[27,28]$ and its antipsoriatic effect could be due to different mechanisms, principally involving folate antagonist, decreased cell proliferation, suppression of T-cell activation ( through a folate related mechanism) [29]. Diversity of the antipsoriatic mechanism of NS and MTX may in part explain the augmented antipsoriatic effect of combining MTX + NS.

In the present study, MDA, an indicator of oxidative stress was found high in psoriatic patients which then declined after 12 weeks of treatment in the group receiving NS compared with pretreatment levels. It is not yet clear whether this reduction in oxidative stress is due to an antioxidant effect of NS or could be due to improvement in psoriatic lesion that lead to reduction in oxidative stress. MTX induced elevation in SMDA may indicate that MTX clear psoriatic lesion by mechanism not involving antioxidant effects. Furthermore, combining NS + MTX have the advantages of reversing the oxidative stress of MTX, and as a result, may offer another advantage since NS has been shown in animal model protective to the liver against CCL4 [30] or INH [9] and therefore can be expected to prevent MTX induced liver or other organs injury such the bone marrow or the lungs. Such effect warrants further confirmation. The present study revealed that administering NS + MTX significantly abolished gastrointestinal upset which was almost invariably reported by patients receiving oral MTX, a benefit most patients confidently recognized.

Patients treated with NS (topical + oral) were highly satisfied with the treatment since most of them had tried different medications in the past and experienced all forms of side effects. They found, in addition, the aromatic smell of NS pleasant, and it did not stain clothes as other topical preparations did. The least satisfaction rate was reported with MTX because of sever gastric upset and most patients are reluctant to accept a drug which is labeled as a chemotherapeutic agent. Lack of satisfaction with MTX may contribute to a high relapse rate $(50 \%)$ and discontinuation of the drug in spite of an initial good response. Relapse rate with NS or the combination was lower than MTX and reported in one third of patients. It is worth mentioning that seasonal variation an important factor in exacerba- 
tion and remission of the disease. We tried our best to complete the study during winter to exclude effects attributed to environmental factors. None of the 3 treatments at the stated doses changed liver enzymes or blood count. The effect of MTX on liver enzymes is dose and duration dependent and the dose of MTX was small and for short duration which is not expected to alter liver enzymes. Topical use of NS did not cause dermatological side effects, although in one study on human it was reported that topical uses of NS caused contact dermatitis [31]. The result of the present study confirms our previous observation on the effect of NS as an effective treatment of psoriasis [7] and also in agreement with an experimental study which showed that the extract of NS seeds demonstrated antipsoriatic effect in mouse tail model for psoriasis [32]. It can be concluded that NS has antipsoriatic effect and also augmented the antipsoriatic effect of MTX in patients with palmoplantar psoriasis. NS completely abolished gastric upset induced by MTX.

\section{REFERENCES}

1. James W D, Berger TG, Elston DM. Seborrheic Dermatitis, Psoriasis, Recalcitran Palmoplantar Eruptions, Pustular Dermatitis and Erythroderma. In Andrew's the clinical dermatology of the skin disease. 11th ed. Saunders Elsevier 2011; 188-202.

2. Kurd SK, Gelfand JM. The prevalence of previously diagnosed and undiagnosed psoriasis in US adults: results from NHANES 2003-2004. J Am Acad Dermatol 2009:60:218-224.

3. Tristani-Firouzi P, Krueger GG. Efficacy and safety of treatment modalities for psoriasis. Cutis 1998; 61: 1121.

4. Fowler JF, Duh MS, Rovba L, et al. The impact of psoriasis on health care costs and patient work loss. J Am Acad Dermatol 2008;59:772-780.

5. Ghorbanibirgani A, Khalili A, Rokhafrooz D. Comparing Nigella sativa Oil and Fish Oil in Treatment of Vitiligo. Iran Red Crescent Med J 2014;16:1-5.

6. Yousefi M, Barikbin B, Kamalinejad M, et al. Comparison of therapeutic effect of topical Nigella with Betamethasone and Eucerin in hand eczema. J Eur Acad Dermatol Venereol 2013;27:1498-1504

7. Ahmed JH, Ibraheem AY, Al-Hamdi KI. Evaluation of efficacy, safety and antioxidant effect of Nigella sativa in patients with psoriasis: A randomized clinical trial. J Clin Exp Invest 2014;5:186-193

8. Burits M, Bucar F. Antioxidant activity of Nigella sativa essential oil. Phytother Res 2000;14: 23-328.

9. Hassan AS, Ahmed JH, Al-Haroon SS. A study of the effect of Nigella sativa (Black seeds) in isoniazid (INH)- induced hepatotoxicity in rabbits. Indian J Pharmacol 2012;44:678-682.

10. Röhrig B, du Prel J, Wachtlin D, et al. Sample size calculation in clinical trials. Dtsch Arztebl Int 2010;107:552-556.

11. Ozel MZ, Kaymaz H. Superheated water extraction, steam distillation and Soxhlet extraction of essential oils of Origanum onites. Anal Bioanal Chem 2004;379:1127-1133.

12. Dave's M.(2003). The Psoriasis Area and severity Index: Internet http://www.Dave'sPsoriasisInfo.com

13. Carlin CS, Feldman SR, Krueger JG, et al. A 50\% reduction in the Psoriasis area and Severity Index (PASI 50 ) is a clinical significant endpoint in the assessment of Psoriasis. J Am Acad Dermatol 2004;50:859- 866.

14. Bueg JA, Aust SD. Microsomal lipid peroxidation Method Enzymol 1978;52:302-310.

15. Janagond, AB , Kanwar AJ, Handa S. Efficacy and safety of systemic methotrexate vs. acitretin in psoriasis patients with significant palmoplantar involvement: a prospective, randomized study. J Eur Acad Dermatol Venereol 2013;27:384-389.

16. Abel-Salam BK. Immunomodulatory effects of black seeds and garlic on alloxan-induced Diabetes in albino rat. Allergol Immunopathol (Madr) 2012;40:336340.

17. Yi T, Cho SG, Yi Z, et al. Thymoquinone inhibits tumor angiogenesis and tumor growth through suppressing AKT and extracellular signal-regulated kinase signaling pathways. Mol Cancer Ther 2008;7:1789-1796.

18. Peng L, Liu A, Shen Y, et al. Antitumor and anti-angiogenesis effects of thymoquinone on osteosarcoma through the NF-kB pathway. Oncol Rep 2013;29:571578.

19. Li F, Rajendran P, Sethi G. Thymoquinone inhibits proliferation, induces apoptosis and chemosensitizes human multiple myeloma cells through suppression of signal transducer and activator of transcription 3 activation pathway. Br J Pharmacol 2010;161:541-554.

20. Tripathi YB, Chaturvedi AP, Pandey N. Effect of Nigella sativa seeds extracts on iNOS through antioxidant potential only: crude/total extract as molecular therapy drug. Indian J Exp Biol 2012;50:413-418.

21. Woo CC, Kumar AP, Sethi G, Tan KH. Thymoquinone: potential cure for inflammatory disorders and cancer. Biochem Pharmacol 2012;83:443-451.

22. Hannan A, Saleem S, Chaudhary S, Antibacterial activity of Nigella sativa against clinical isolates of methicillin resistant Staphylococcus aureus. J Ayub Med Coll Abbottabad 2008;20:2-74.

23. Kanter M, Coskun O, Uysal $\mathrm{H}$. The antioxidative and antihistaminic effect of Nigella sativa and its major constituent, thymoquinone on ethanol-induced gastric mucosal damage. Arch Toxicol 2006;80:217-224.

24. Ahmed JH, Abd SR, Al-hamdi KI. Effectiveness of oral zinc sulfate, oral methotrexate and their combi- 
nation in the treatment of psoriasis. J Clin Exp Invest 2010;1:134-149.

25. Woźniak A, Drewa G, Krzyzyńska-Maliniowska E, et al. Oxidant-antioxidant balance in patients with psoriasis. Med Sci Monit 2007;13:30-33.

26. Ramadan R, Tawdy A, Abdel Hay R, The antioxidant role of paraoxonase 1 and vitamin $E$ in three autoimmune diseases. Skin Pharmacol Physiol 2013;26:2-7.

27. Ayromlou H, Hajipour B, Hossenian MM, et al. Oxidative effect of methotrexate administration in spinal cord of rabbits. J Pak Med Assoc 2011;61:1096-1099.

28. Oktem F, Yilmaz HR, Ozguner F, et al. Methotrexateinduced renal oxidative stress in rats: the role of a novel antioxidant caffeic acid phenethyl ester. Toxicol Ind Health 2006;22:241-247.
29. Puig L. Methotrexate: New Therapeutic Approaches. Actas Dermosifiliogr 2014;105:583-589

30. Mansour MA, Ginawi OT, El-Hadiyah T, et al. Effects of volatile oil constituents of Nigella sativa on carbon tetrachloride-induced hepatotoxicity in mice: evidence for antioxidant effects of thymoquinone. Res Commun Mol Pathol Pharmacol 2001;110:239-251.

31. Nosbaum A, Ben Said B, Halpern SJ, et al. Systemic allergic contact dermatitis to black cumin essential oil expressing as generalized erythema multiforme. Eur $\mathrm{J}$ Dermatol 2011;21:447-448.

32. Dwarampudi LP, Palaniswamy D, Nithyanantham M, Raghu PS. Antipsoriatic activity and cytotoxicity of ethanolic extract of Nigella sativa seeds. Pharmacogn Mag 2012;8:268-272. 